\title{
Seasonal Variation of Aedes taeniorhynchus (Wiedemann) at the International Airport, Isla Verde, Puerto Rico'
}

\author{
Irving Fox, Gisela A. Rivera, and Ileana G. Bayona ${ }^{2}$
}

\section{INTRODUCTION}

The black salt-marsh mosquito, Aedes taeniorhynchus (Wiedemann) is the most abundant of the many species known to come to light-traps in the vicinity of the International Airport, Isla Verde, P.R., and among the worst of the vicious bloodsucking pests which interfere with the thriving tourist industry there. Its tendency to vary seasonally in abundance according to a definite pattern was indicated by light-trap surveys in 1956 and 1957..$^{3}$ The purpose of this paper is to present the results of 8 years of further study (1958-65), the objective of which was to answer the following questions: Is seasonal incidence consistent from year to year; what is the relationship to inches of rainfall and heights of tides; and can light-trap counts be relied upon as a true index of natural variation in abundance?

\section{METHODS}

Three New Jersey-type light-traps were operated from 1958 through 1963 and two in 1964 and 1965, using 40-watt light bulbs. They were located in the same places as described in a previous report, ${ }^{4}$ namely: Lt. ${ }^{5} 1$, Yacht Club, Boca de Cangrejos; Lt. 4, Transformer, Airport proper; and Lt. 7, National Guard, Air National Guard Area (fig. 1). The light-traps were run nightly and collections were made three times per week. Normally there were more than 25 trap-nights each month and over 300 per year. After 1963 Lt. 4 had to be eliminated. From 1961 through 1965 mosquitoes

1 This investigation was supported by the Puerto Rico Department of Health, Research Grant GM-07152 from the National Institute of General Medical Sciences, and Graduate Research Training Grant 5-TI AI 15 from the National Institute of Health, U.S. Public Health Service.

${ }^{2}$ School of Medicine, School of Tropical Medicine, University of Puerto Rico, San Juan, P.R. The authors wish to express their appreciation to Francisco Romero, Wigberto Trujillo, Angel Del Moral, Robert I. Fox, Virginia Iñigo, and John O'Brien for assistance in making collections and counting mosquitoes.

${ }^{3}$ Fox, I., The mosquitoes of the International Airport, Isla Verde, Puerto Rico, as shown by light-traps, Mosquito News, 18: 117-24, 1958.

- Fox, I. and Garcia-Moll, I., The Culicoides of the International Airport, Isla Verde, Puerto Rico, as shown by light-traps, Mosquito News 21: 120-32, 1961.

${ }^{5}$ Lt. stands for light-trap. 
were also collected as they came to bite a person during a 15-minute period beginning at about 10:00 a.m., usually 10 or more times per month. The biting station was located about one-fourth mile northeast of Lt. 1 (Yacht Club) across the laguna as indicated on the map (fig. 1). The rainfall in

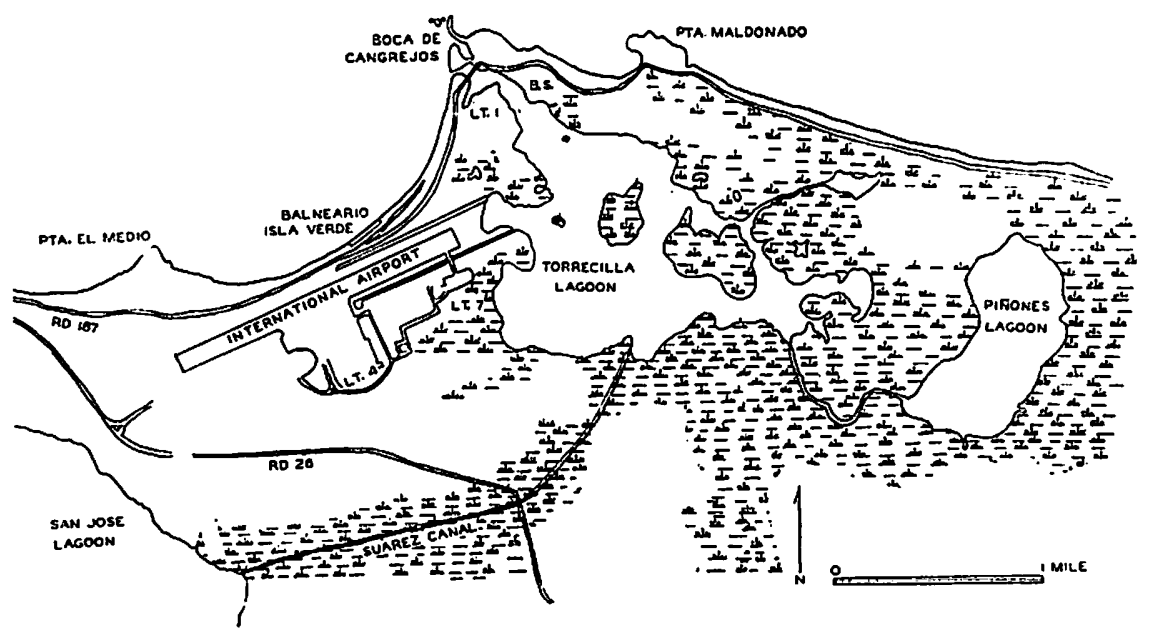

Frg. 1.-Map of the International Airport and vicinity, Isla Verde, P.R., showing the locations of the 3 light-traps (Lt. 1, Lt. 4, and Lt. 7) and the Biting Station (B.S.).

TABLe 1.-Yearly average per light-trap night of Aedes taeniorhynchus, and yearly rainfall in inches

\begin{tabular}{c|r|r|r|r|r}
\hline Year & Rainfall & Lt. 1 & Lt. 4 & Lt. 7 & \multicolumn{1}{|c}{ Total } \\
\cline { 2 - 3 } & 74.05 & 3 & 12 & 18 & 11 \\
1958 & 51.65 & 97 & 124 & 344 & 185 \\
1960 & 64.40 & 26 & 19 & 136 & 60 \\
1961 & 61.51 & 24 & 8 & 118 & 50 \\
1962 & 54.85 & 8 & 4 & 90 & 36 \\
1963 & 48.61 & 45 & 23 & 179 & 81 \\
1964 & 47.54 & 59 & ND $^{1}$ & 441 & 250 \\
1965 & 65.81 & 62 & ND & 261 & 162 \\
\hline
\end{tabular}

$1 \mathrm{ND}=$ not done. Lt. stands for light-trap.

inches was obtained from U.S. Weather Bureau reports (Local Climatological Data, U.S. Department of Commerce, Environmental Science Service Administration) pertaining to the Isla Verde Airport. The average monthly predicted heights of the tides in feet were derived from Tide 
Tables (U.S. Department of Commerce, Coast and Geodetic Survey) by averaging the two high tides of each day, and dividing the total sum of the averages by the number of days in the month.
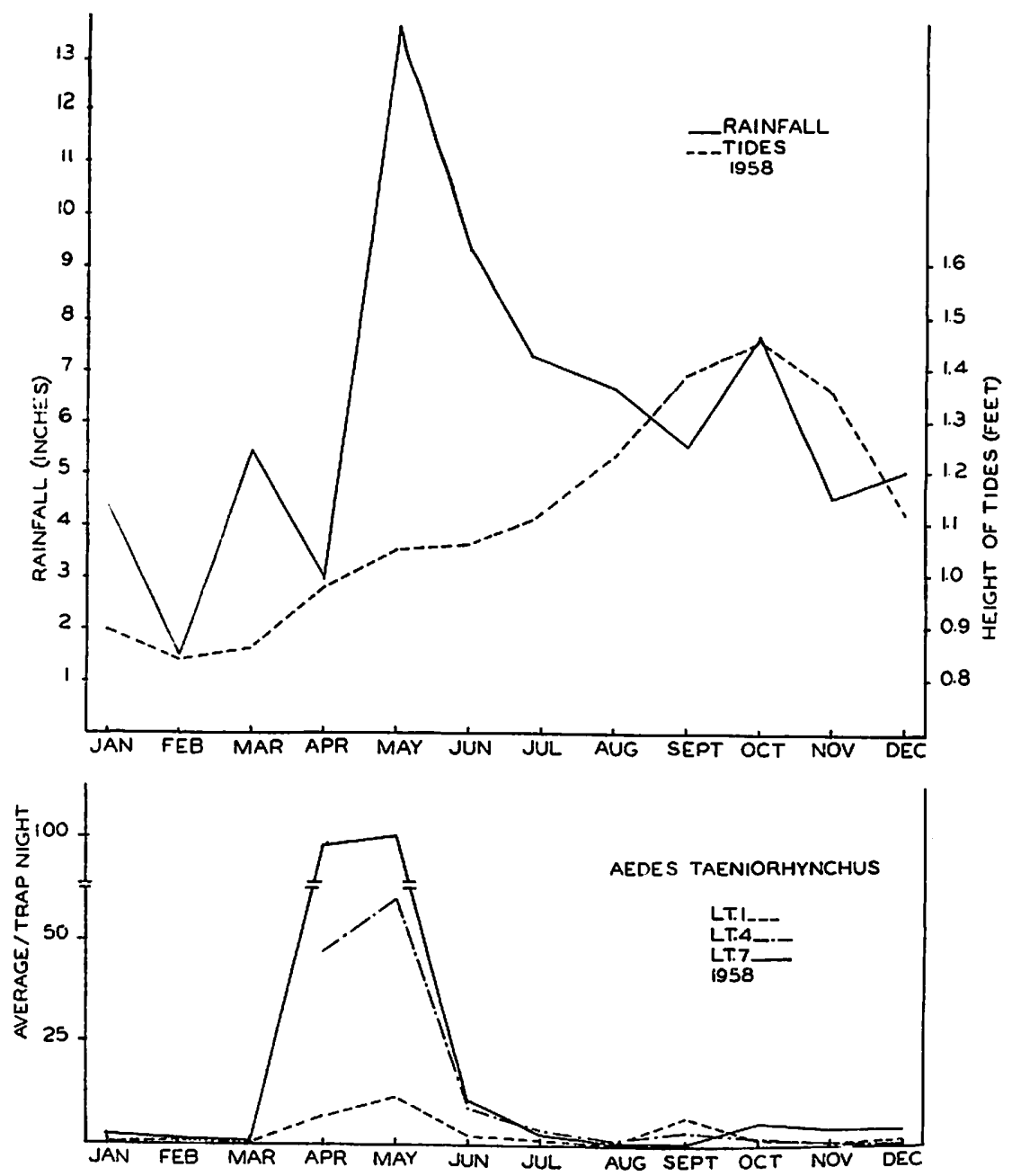

FIG. 2.-Monthly average per light-trap night of $A$. taeniorhynchus compared with monthly rainfall and average predicted height of the tide in 1958.

\section{RESULTS}

Table 1 shows that the year of greatest rainfall, 1958, yielded the lowest total average of $A$. taeniorhynchus and the year of least rainfall, 1964, yielded the most mosquitoes. But the other years did not indicate either increase or decrease with heavy or light rainfall. In 1960 the averages of 

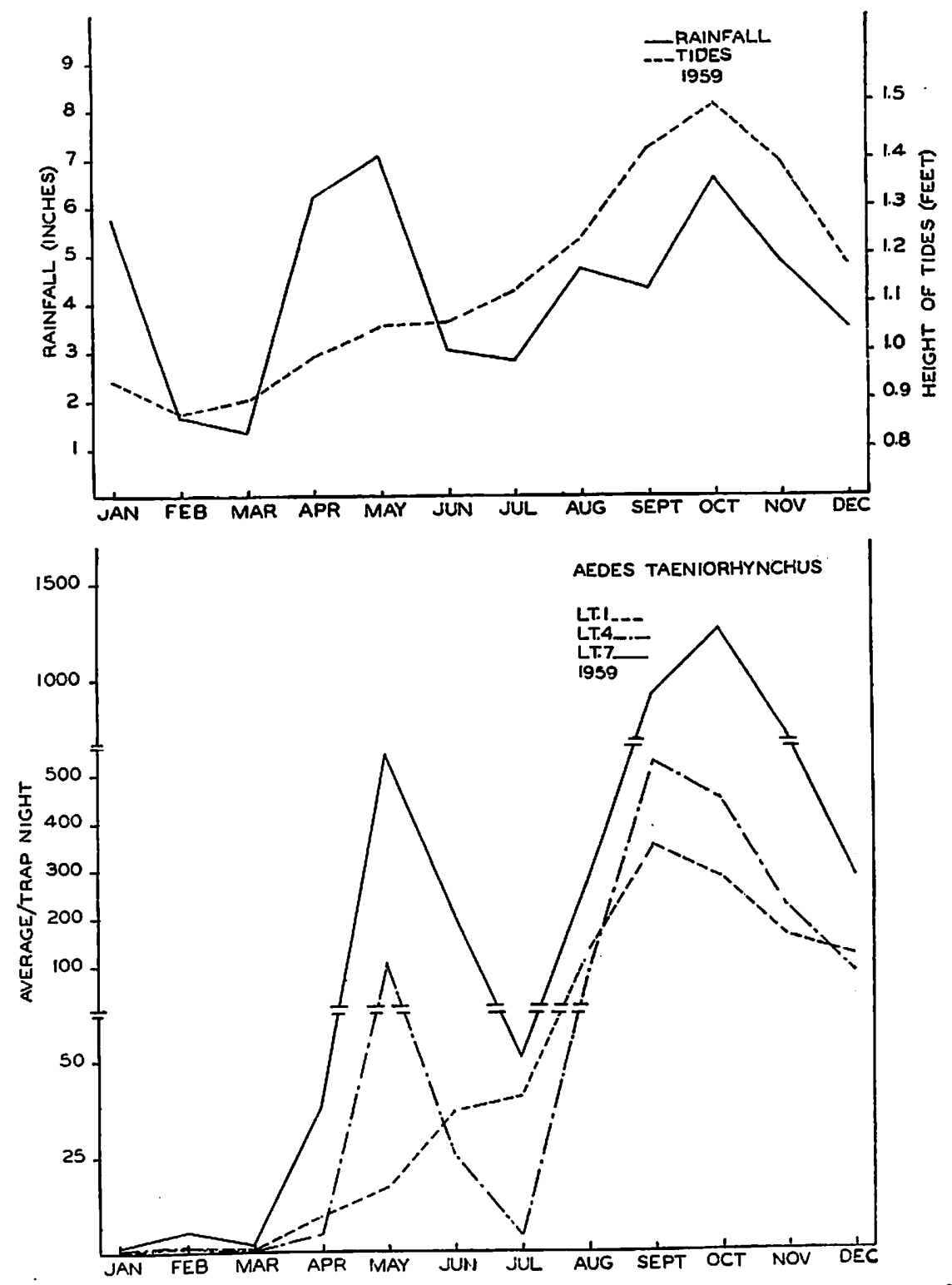

FiG. 3.-Monthly average per light-trap night of $A$. taeniorhynchus compared with monthly rainfall and average predicted height of the tide in 1959.

light-traps 1 and 7 were about one-half those of 1965 , although there was only about 1 inch difference in rainfall. The range of variation in annual yield from light-trap to light-trap and from year to year was very wide. The monthly rainfall and the predicted height of the tide of each year 

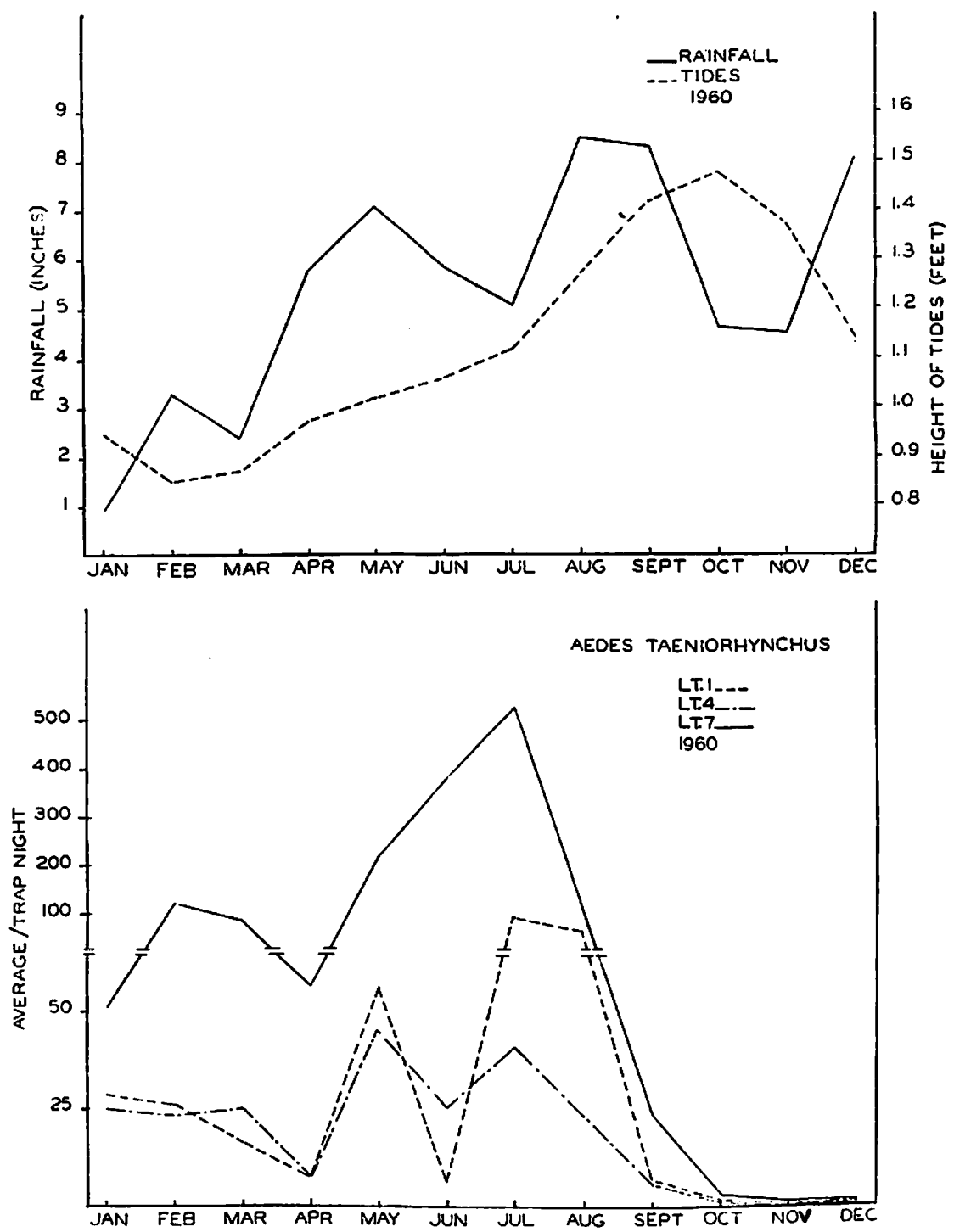

FIG. 4.-Monthly average per light-trap night of $A$. taeniorhynchus compared with monthly rainfall and average predicted height of the tide in $\mathbf{1 9 6 0}$.

are compared with the monthly average per trap-night of each light-trap in figures 2 to 9 . With the exception of 1963 (fig. 7) there were relatively few mosquitoes in January, February, and March. Similarly, except for 1959 (fig. 3) and 1962 (fig. 6), November and December were months of com- 

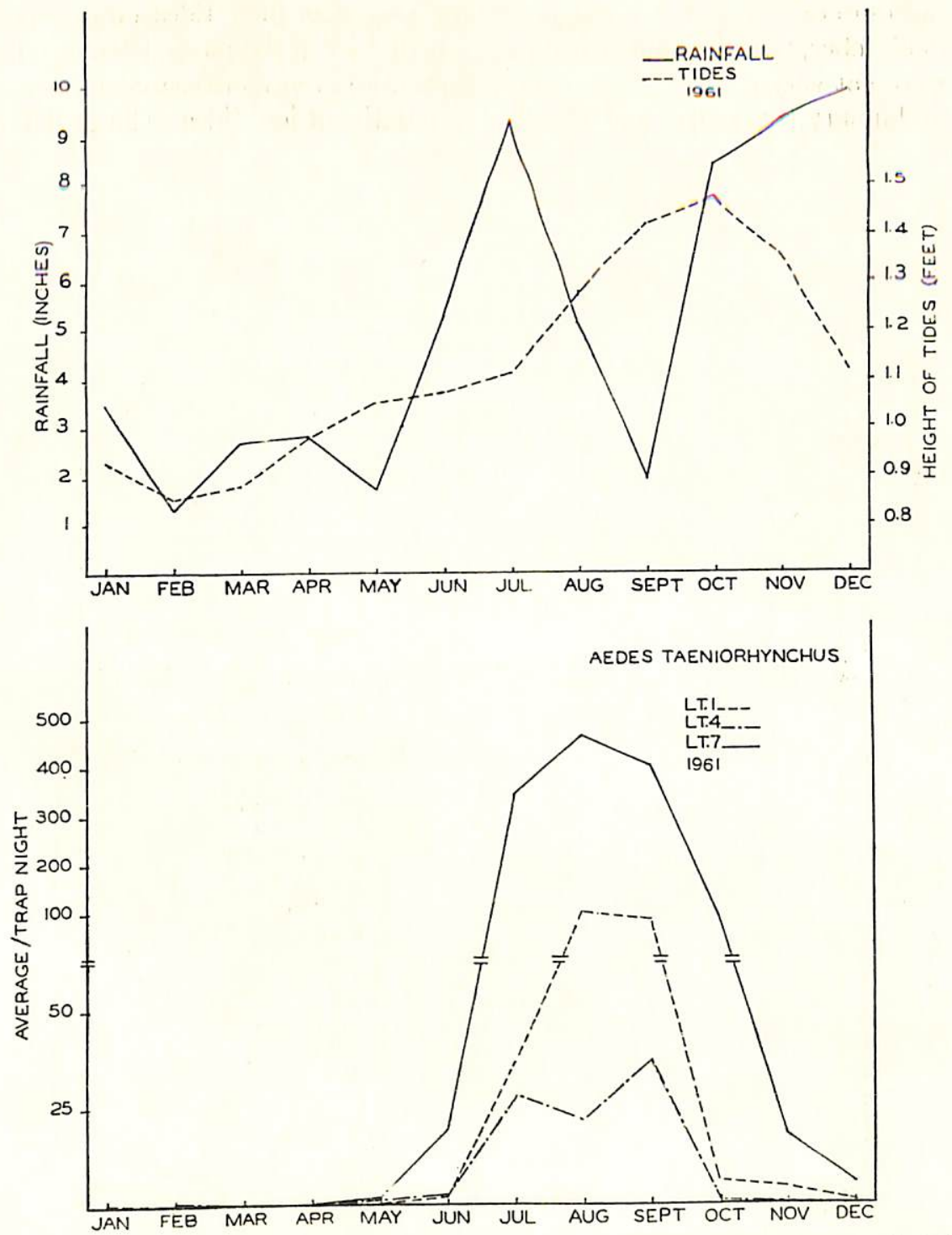

FIG. 5.-Monthly average per light-trap night of A. taeniorhynchus compared with monthly rainfall and average predicted height of the tide in 1961 .

paratively low incidence. In general, the months of greatest mosquito abundance, April through October, included the peak periods of rainfall each year. There were some notable exceptions; thus high rainfall in November and December of 1961 was not accompanied by an increase in 
mosquitoes. Figures 2 through 9 show also that high tides occurred in September, October, and November, a period when the mosquitoes usually were not very abundant. The mosquitoes were even more scarce, however, in January, February, and March, the months of low tides. The peaks of
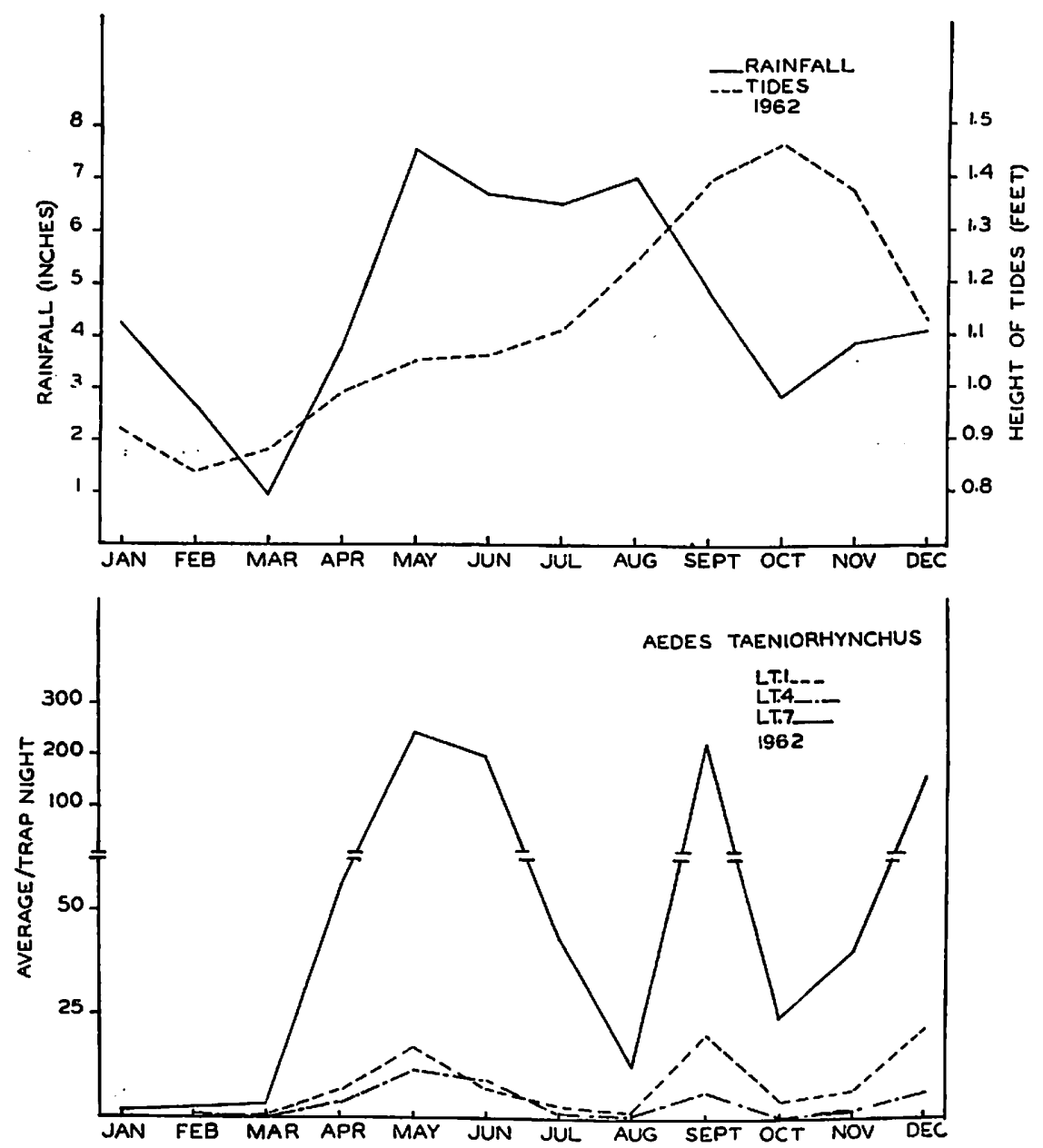

Frg. 6.-Monthly average per light-trap night of $A$. taeniorhynchus compared with monthly rainfall and average predicted height of the tide in 1962.

A. taeniorhynchus abundance did not correspond with the lowest tides ever, and only in 1959 (fig. 3) did they correspond with the highest tides.

The three light-traps were uniform as regards the pattern of peaks and recessions in abundance during any given year. However, the yields were very different with Lt. 7 giving most mosquitoes and Lt. 1 giving least. 

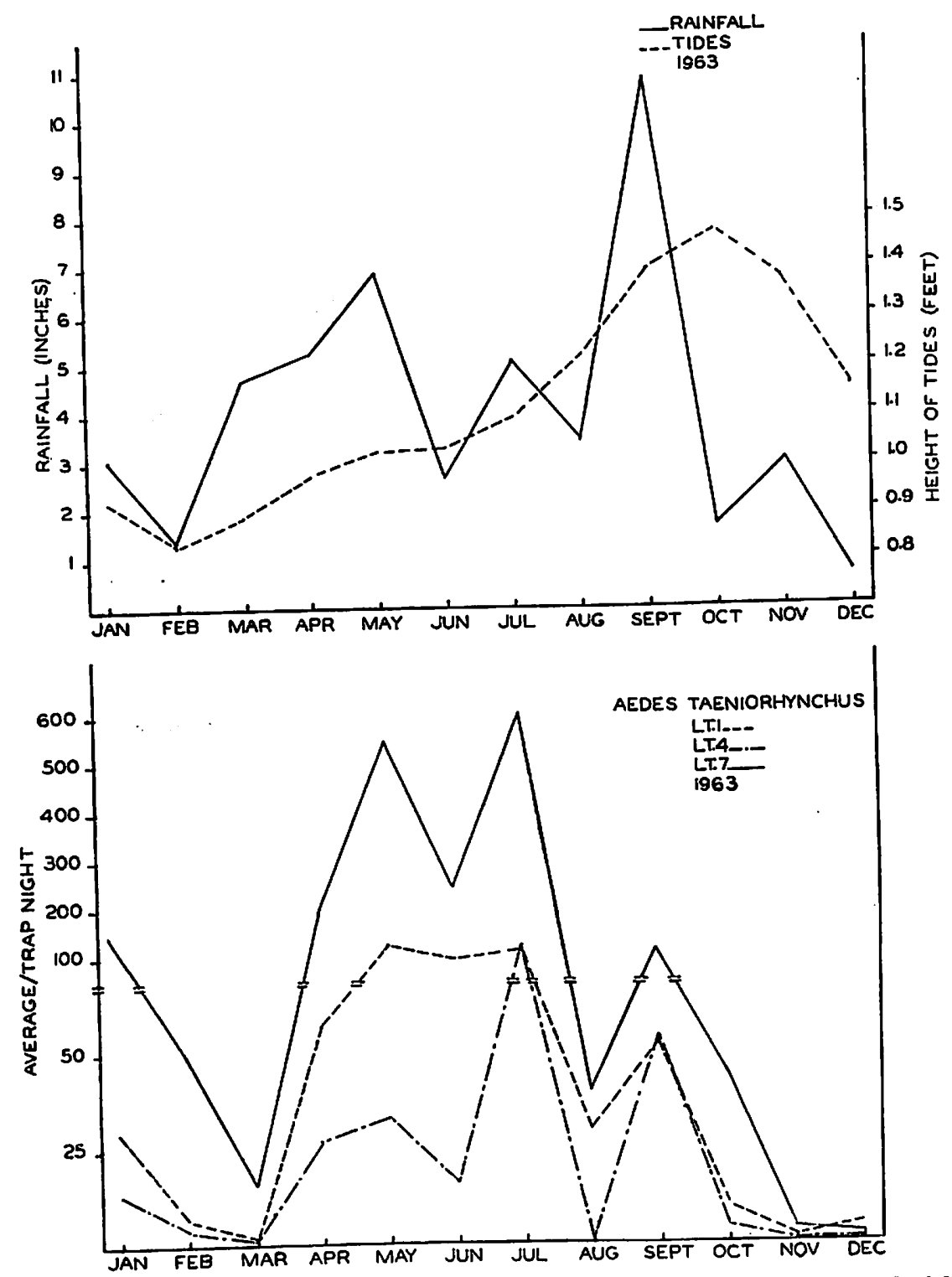

Fra. 7.-Monthly average per light-trap night of $A$. taeniorhynchus compared with monthly rainfall and average predicted height of the tide in 1963.

During peak months of most years Lt. 7 yielded about 5 times as many mosquitoes as Lt. 1; but during the recessions of January, February and March of most years there were often as few mosquitoes from Lt. 7 as from Lt. 1. 

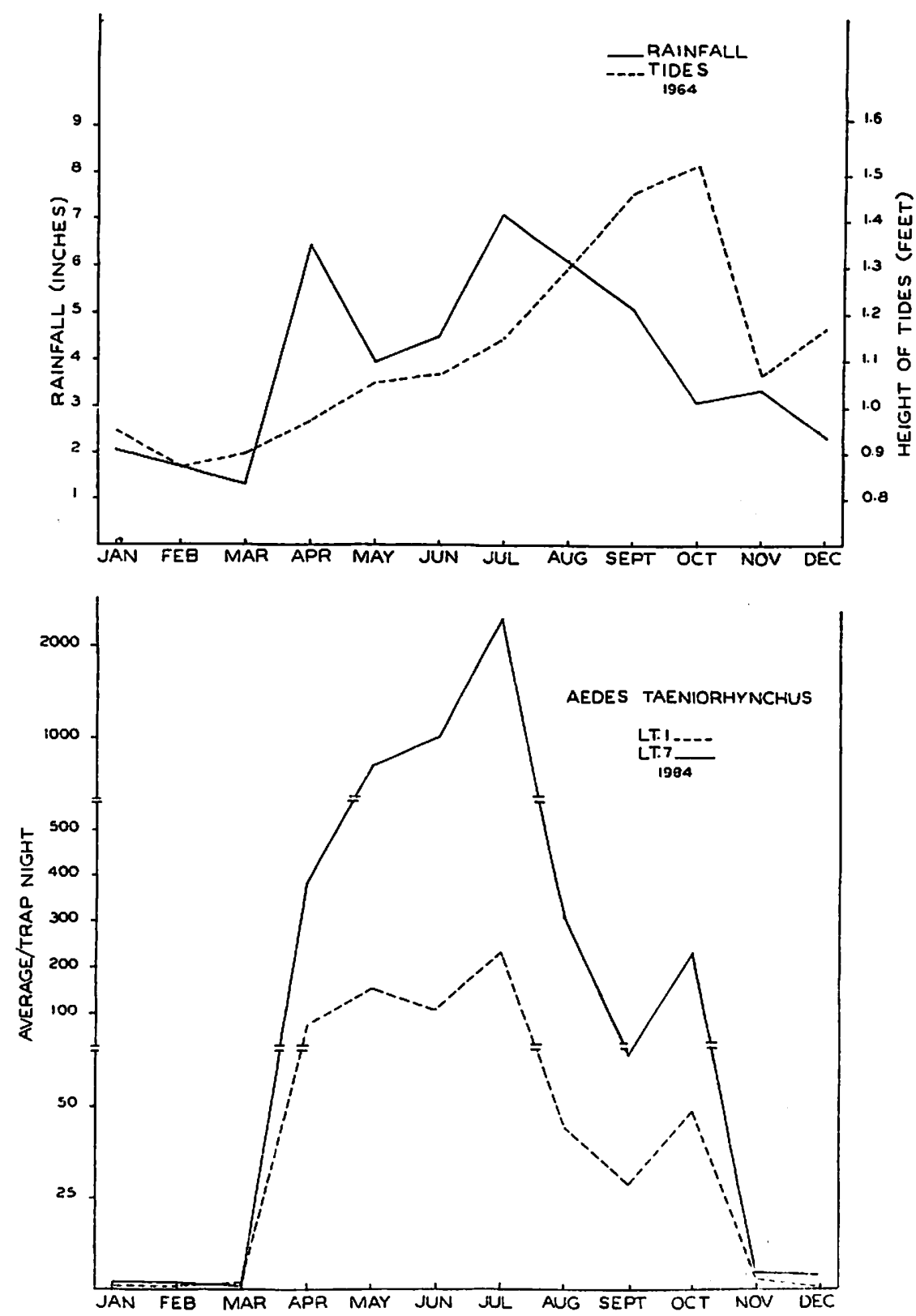

Fra. 8.-Monthly average per light-trap night of A. taeniorhynchus compared with monthly rainfall and average predicted height of the tide in 1964. 

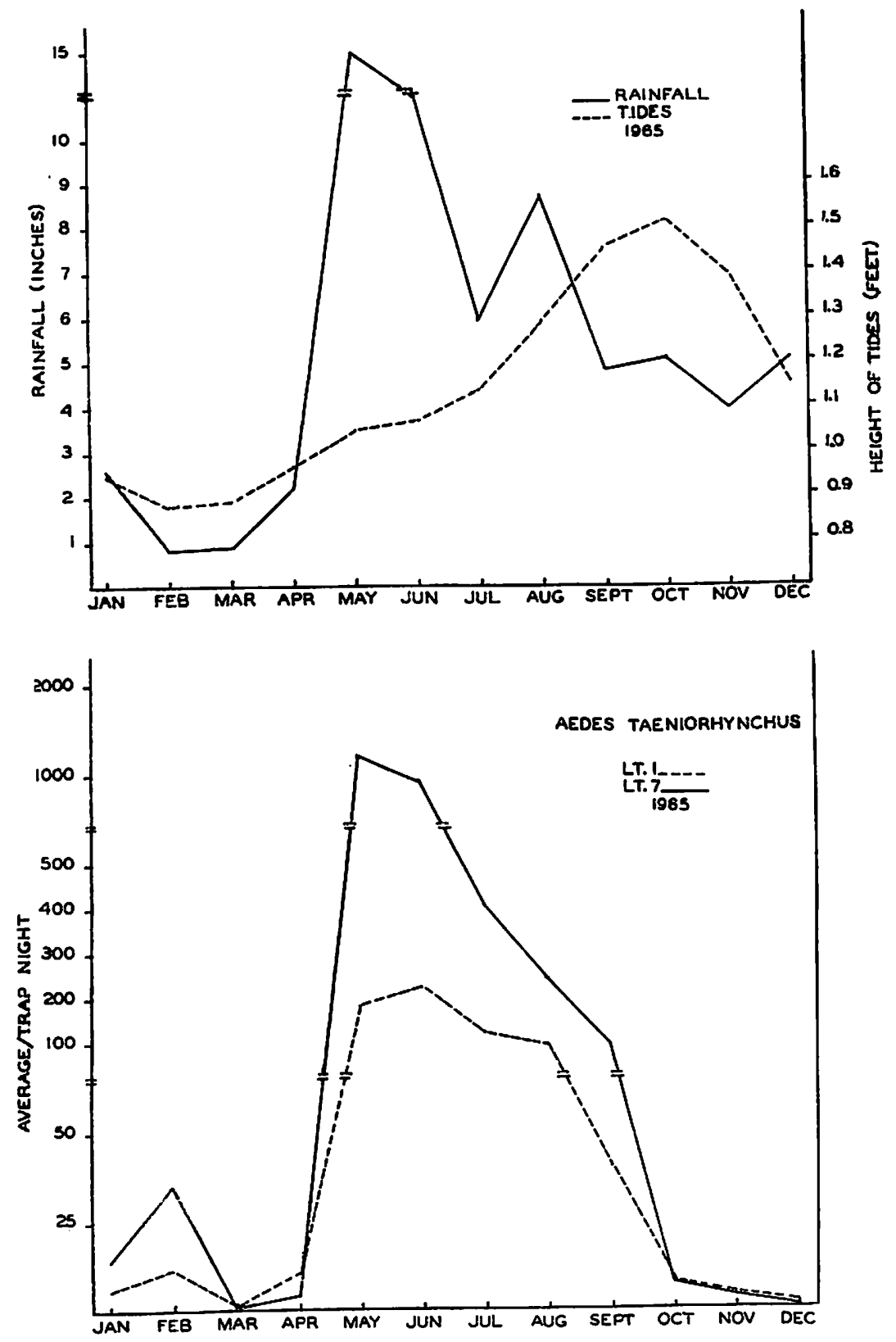

FIG. 9.-Monthly average per light-trap night of $A$. taeniorhynchus compared with monthly rainfall and average predicted height of the tide in 1965 . 


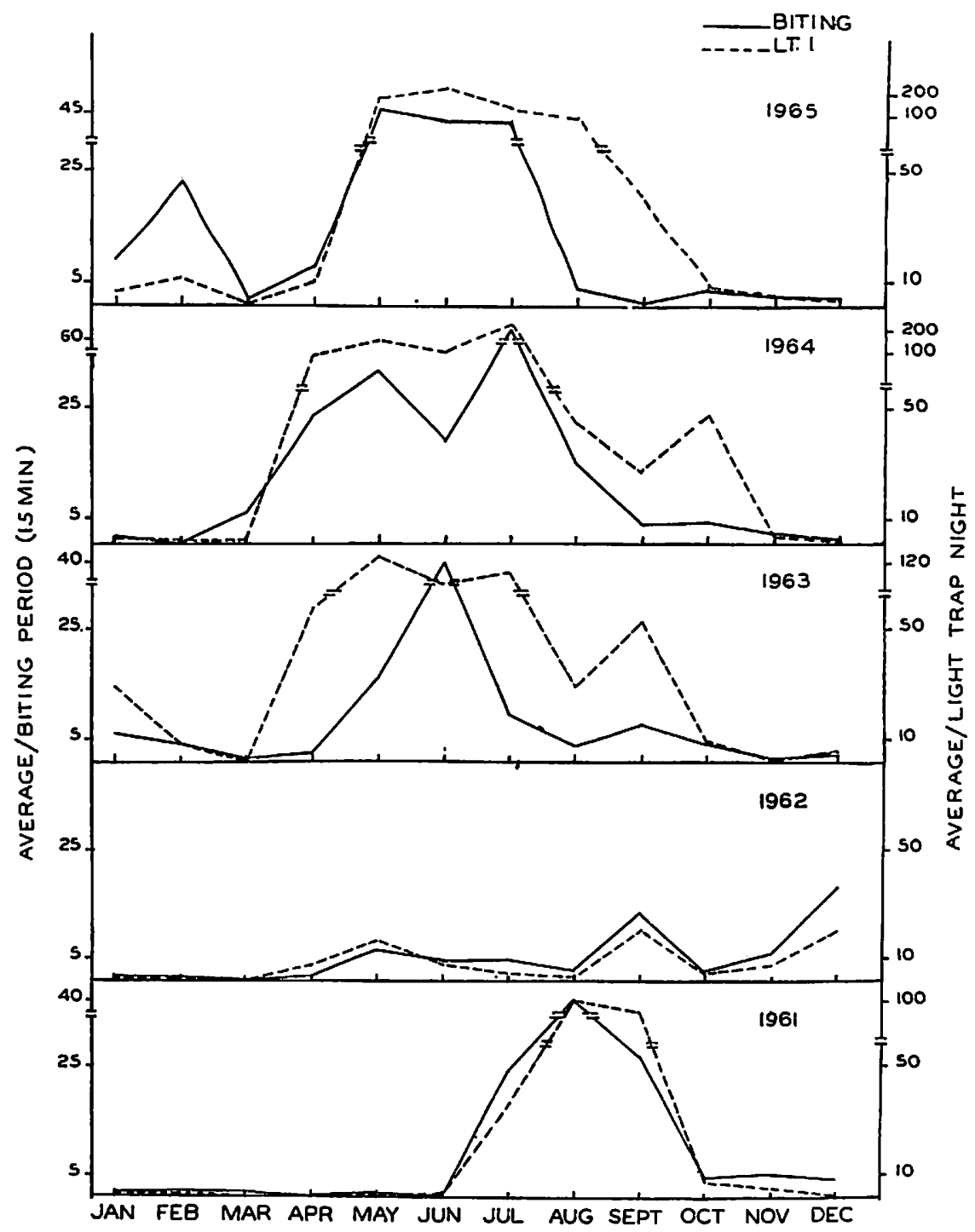

Fia. 10.-Average number of $A$. taeniorhynchus taken while biting a person during 15-minute biting periods about 10 times per month compared with the monthly average per light-trap night from Lt. 1 .

In figure 10 the results from the biting station are compared with those from the light-trap nearest it, Lt. 1, Yacht Club, for a 5-year period, 19611965. In general, the peaks and recessions of $A$. taeniorhynchus abundance as shown by both methods of capture corresponded to a remarkable degree. 
An ideal year was created with the monthly data pooled by adding the figures for each month of each year from 1961 through 1965 and dividing by 5 . The results in figure 11 show a close correlation between the bitingstation counts and the counts from the nearest light-trap.

\section{DISCUSSION}

The advantages of keeping this type of data involving charts of light-trap counts and biting counts are twofold. First, in control operations personnes

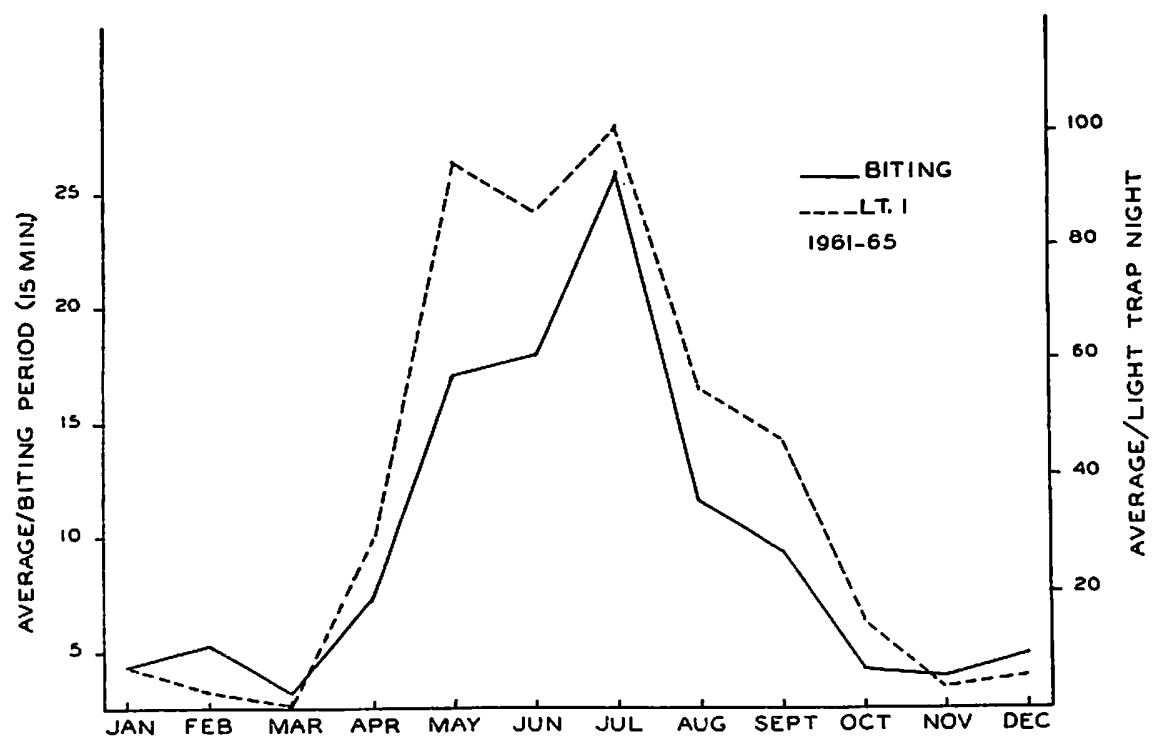

FIG. 11.-Monthly average biting counts compared with monthly average Lt. 1 counts for the years 1961 through 1965, the data being pooled and averaged to form an ideal year.

and supplies may be adjusted to predicted seasonal needs. Second, the knowledge that low incidence could be due to natural seasonal or yearly variation may prevent a false conclusion that control measures have been successful. Since figures 2 to 11 show that there occurred periods during each year when very few or no $A$. taeniorhynchus were taken in the lighttraps, or while biting, the criterion for successful control would have to be zero or almost zero light-trap and biting counts every month of the year.

\section{SUMMARY}

From 1958 through 1965 we operated several New Jersey light-traps nightly at Isla Verde, Puerto Rico to find out whether the abundance of Aedes taeniorhynchus varied according to a definite seasonal pattern, and 
whether the variation was related to inches of rainfall or to predicted heights of the tides. To prove that the number of specimens caught by the traps correlated closely with the numbers in nature we regularly counted those coming to bite a man at a station near one of the traps.

Graphs showing the monthly average number of specimens of $A$. taeniorhynchus per light-trap night revealed a seasonal pattern which was reasonably consistent from year to year. In general, the season of greatest abundance began in April and terminated in October, while the period of low incidence was November through March. The yearly average per light-trap night did not increase or decrease with the annual total inches of rainfall. Years of light rainfall may result in more mosquitoes than do those of heavy precipitation. Peak months of mosquito abundance on the graphs, however, often coincided with peak months of rainfall. Monthly high or low tides were not correlated with peaks or recessions of mosquitoes. The number of specimens caught in the light-traps was in direct proportion to the number biting man in the vicinity.

\section{RESUMEN}

De 1958 a 1965, inclusive, se instalaron en Isla Verde, Puerto Rico, varias trampas de luz para observarlas de noche y determinar si la población del mosquito Aedes taeniorhynchus variaba según la estación del año y si la variación estaba relacionada con la precipitación pluvial o el pronóstico de la altura de las mareas. Para probar que existía una estrecha correlación entre el número de especímenes atrapados y el número que existía en el ambiente natural, regularmente se contaban los que picaban a un hombre estacionado en las cercanías de una de las trampas.

Las gráficas que mostraban el número de especímenes de $A$. taeniorhynchus por trampa de luz por noche revelaron un patrón estacional razonablemente consistente año tras año. En general, la estación en que más abundaban comenzaba en abril y terminaba en octubre, mientras que el periodo de menor incidencia era el de noviembre a marzo. El promedio anual de especímenes por trampa de luz por noche no aumentó ni disminuyó según el total de la precipitación pluvial al año. En años de poca lluvia, puede haber más mosquitos que en los de mucha lluvia. Sin embargo, en las gráficas a menudo coincidieron los meses de mayor abundancia de mosquitos con los de mayor lluvia. Por otro lado, las altas o las bajas mareas, según los records mensuales, no estaban correlacionados con la abundancia o disminución de los mosquitos. El número de los especímenes que se cogieron en las trampas de luz sí estaba en proporción directa con el número de los que picaban al hombre estacionado en la proximidad de una de las trampas. 